\title{
Aesthetic function of literature and the mission of letters in stories
}

\section{Susana MAMADALIYEVA ${ }^{1}$}

Karshi State University

\begin{tabular}{l} 
ARTICLE INFO \\
\hline Article history: \\
Received March 2021 \\
Received in revised form \\
20 March 2021 \\
Accepted 15 April 2021 \\
Available online \\
20 May 2021 \\
\\
\hline Keywords: \\
letter, \\
place, \\
tense, \\
diplomatic letter, \\
loving letter, \\
detail, \\
solution, \\
hero portrait, \\
conflict, \\
solution, \\
conclusion.
\end{tabular}

\begin{abstract}
Letters serve as a valuable source for studying not only the life and work of writers and critics, but also the period, history, reasons for writing, and the secrets of a particular work with all its contradictions. Alisher Navoi's letters to Munshaot have their own peculiarities, and their lack of study in Uzbek literature makes it necessary to study this topic. This determines the relevance of the topic we have chosen. To achieve this goal, the following tasks have been identified: to explain the nature and peculiarities of the letter genre; Determining the place of the letter in the works of Alisher Navoi; give different classifications of letters; to determine the place of the letters of the great poet in the life of that period; study the goals, objectives, scope of the letter genre; It is to reveal the significance of Navoi's letters. To show the role of the genre in the development of Alisher Navoi and classical literature on the basis of analysis, research, to give certain generalized conclusions.
\end{abstract}

2181-1415/C) 2021 in Science LLC.

This is an open access article under the Attribution 4.0 International (CC BY 4.0) license (https://creativecommons.org/licenses/by/4.0/deed.ru)

\section{Adabiyotning estetik funksiyasi va hikoyalardagi maktublarning funksiyasi}

\author{
Kalit so'zlar: \\ maktub, \\ makon, \\ zamon, \\ detal, \\ diplomatic maktub, \\ ishqiy maktub, \\ qahramon ruhiyati, \\ konflikt, \\ yechim, \\ xotima.
}

\begin{abstract}
ANNOTATSIYA
Maktublar nafaqat yozuvchi va tanqidchilar hayoti va ijodini, balki davr, tarix, yozilish sabablari va muayyan ziddiyatlar bilan ma'lum bir asar sirlarini o'rganish uchun qimmatli manba bo'lib xizmat qiladi. Alisher Navoiyning Munshaotga yozgan xatlari o'ziga xos xususiyatlarga ega va ularning o'zbek adabiyotida o'rganilmaganligi bu mavzuni o'rganish zaruratini keltirib chiqaradi. Bu biz tanlagan mavzuning dolzarbligini belgilaydi. Ushbu maqsadga erishish uchun quyidagi vazifalar belgilandi: harf janrining mohiyati va o'ziga xos xususiyatlarini
\end{abstract}

${ }^{1}$ Lecturer, Karshi State University, Karshi, Uzbekistan.

E-mail: Susana@gmail.com. 
tushuntirish; AlisherNavoiy asarlarida xatning o'rnini aniqlash; harflarning har xil tasniflarini berish; o'sha davr hayotida buyuk shoir maktublarining o'rnini aniqlash; harf janrining maqsadlari, vazifalari, ko'lamini o'rganish; Navoiy maktublarining ahamiyatini ochib berishdir. Alisher Navoiy va mumtoz adabiyot rivojida janrning rolini tahlil, izlanishlar asosida ko'rsatish, ma'lum umumlashtirilgan xulosalar beriladi.

\section{Эстетическая функция литературы и миссия букв в историях}

\begin{tabular}{l}
\hline Ключевые слова: \\
письмо, \\
пространство, \\
время, \\
деталь, \\
дипломатичное письмо, \\
любовное письмо, \\
психология героя, \\
конфликт, \\
завязка, \\
развязка.
\end{tabular}

\begin{abstract}
АННОТАЦИЯ
Письма служат ценным источником для изучения не только жизни и творчества писателей и критиков, но также периода, истории, причин написания и секретов конкретного произведения со всеми его противоречиями. Письма Алишера Навои в Муншаот имеют свои особенности, и их недостаточная изученность узбекской литературой заставляет изучать эту тему. Это определяет актуальность выбранной нами темы. Для достижения этой цели были определены следующие задачи: разъяснить сущность и особенности жанра письма; Определение места письма в творчестве Алишера Навои; давать разные классификации писем; определить место писем великого поэта в жизни того периода; изучить цели, задачи, рамки жанра письма; Он призван раскрыть значение писем Навои. Показать роль жанра в развитии Алишера Навои и классической литературы на основе анализа, исследования, дать определенные обобщенные выводы.
\end{abstract}

Letters are one of the most concise and effective forms of human communication. It reflects the heart, mood, dreams and aspirations of the recipient of the letter together with the writer.

Letters are the expression of a person's secrets. That is why from ancient times the letter was given a lot of attention. It is natural for letters to have different meanings, depending on who they are written to, what kind of relationship they are in, and for what purpose. Letters from great people, writers, critics: personal, friendly letters; sociojournalistic letters; letters of a literary nature; letters to officials, etc. In this regard, the study of the letters of the great Alisher Navoi is an important issue.

Letters serve as a valuable source for studying not only the life and work of writers and critics, but also the period, history, reasons for writing, and the secrets of a particular work with all its contradictions. Alisher Navoi's letters to Munshaot have their own peculiarities, and their lack of study in Uzbek literature makes it necessary to study this topic. This determines the relevance of the topic we have chosen. So with the writer of the letter in them together the mood of the recipient of the letter is reflected in the dreams and aspirations described Letters, descriptions, people's feelings, secrets reveals. Because of this, letters have been the focus of attention since ancient times. The content of the letters may vary. The letters are large according to his classification letters from individuals, 
letters from writers, letters from critics; personal letters, friendly letters, social letters, journalistic letters, of a literary nature letters, letters to officials.

Scientific research of Alisher Navoi's letters. To achieve this goal, the following tasks have been identified: to explain the nature and peculiarities of the letter genre; Determining the place of the letter in the works of Alisher Navoi; give different classifications of letters; to determine the place of the letters of the great poet in the life of that period; study the goals, objectives, scope of the letter genre; It is to reveal the significance of Navoi's letters. To show the role of the genre in the development of Alisher Navoi and classical literature on the basis of analysis, research, to give certain generalized conclusions.

The scientific study and analysis of one of the leading genres in the work of Alisher Navoi, which plays an important role in literature and literary criticism, determines its scientific novelty. If personal messages between people there are seen as a means of communication, letters in the literature are a separate genre, their nature, their forms learning is still an urgent task. [Sh. Ahmedova. Literature of Uzbekistan and art. Article. 2004.]. It turns out that there is a difference between letters and letters. That is, as mentioned above, letters carry information serves and thus communicates. Letters are in formation artistic-aesthetic along with transportation and communication has an impact and also contributes to the rise of fiction. So the letter is, in a sense, a reworked, polished letter, is an artistic form and is a classic as a result of the rise of artistic design the genre appeared in the literature. Names when they first appear poetic and later prose, a letter in Persian literature based on the genre and developed it. A letter in Uzbek classical literature. The origin of the genre is connected with the Khorezmian name.

The letter is a human document. It clearly and objectively expresses the personality of the letter writer, his unique mental state, experiences. The essence of the letter is not the evidence itself, but, first of all, the person and his attitude to it, the expression of personal thoughts, experiences and feelings.

The letter has a certain importance in human life, including in the development of literature, which plays an important role in its spiritual development. In this context, there is a need to divide the letters, first of all, into several groups: personal letters, literary letters, journalistic letters, artistic letters. While personal correspondence between people is seen as a means of communication, correspondence in the literature is a separate genre, and the study of their various forms is one of the important tasks before us.

Letters can be classified according to whom, for what reason, and when. Personal letters can be divided into several types:

1) letters to friends and acquaintances;

2) letters of political and social, journalistic content;

3) letters about literature (to the writer, critic, etc.).

They compare the letter to a mirror, and your letter is like you, just like you. Like a mirror, a letter can accurately reflect both spiritual poverty and "your boiling emotional and intellectual wealth" (Askad Mukhtor). The letter is equal to the writing of each nation. As a result of writing, people also needed to write letters. The oldest example of Khorezmian writing was found in the Castle, which dates back to the 3rd century BC. The monument of the Sogdian inscription is engraved on a pottery vessel found in Tali Barzu (Sogd) and dates back to the 1st century BC. Samples of these inscriptions dating back to the 2 nd and 3rd centuries have been found in Dunhuang (East Turkestan). They contain 
correspondence between a mother living in Samarkand and a girl living in Dunhuang. Correspondence provides information about family life, the high cultural level of the peoples of Central Asia 1.

Our research our object is not samples of the genre, but in the era of new Uzbek literature is a study of letters in created works. Let's talk about it the reason is a matter of letter genesis. Ancient Roman ethicist Lucius Anny Seneca (5th century BC) 65 AD) is one of the pamphlets on ethics There is a work "Ethical Letters to Lutsili". Through it, Lucius explains the rules and etiquette of writing letters to children in ancient Rome. As you can see it is clear that the issue of letters began to receive special attention in Ancient Rome. IV-II millennium BC of the Ancient Aztec state in America According to ancient sources, the secrets of antiquity a type of letter used in the transmission of information between priests also known to science. This is a knotted letter. His secret is known to all only the high priests knew how to speak through it. So,it turns out that the practical need to use letters is to hide secrets, to convey information in an abstract way, to exchange information was.

Oriental scholars paid special attention to the genre of letters. Another letter researcher, Urinbaev Abdurahmon studied letters to Ruqaat in his time selects as the object.

As a result of their in-depth study, XIV-XV over the centuries, the letter genre reached its peak of development emphasizes. [Urinboyev A. Jomiy's letters. Tashkent, 1984]. This genre especially in the work of Alisher Navoi along with the use of the letter as a genre. Of Navoi His letters to his contemporaries are included in "Munshaot" [H. Homidiy, Sh. Abdullayeva, S. Ibrohimova, 1967]. These are two examples A leading source for epistolary literature of the fourteenth and fifteenth centuries listed in the Dictionary of Literary Terms. To Farhod's Shirin in Alisher Navoi's epic "Farhad and Shirin". The letters he sent are the best examples of romantic letters. These are birds, pigeons, and horsemen acted as couriers during the period. By the time of the khanates, letters were sent by couriers, ambassadors or secret messengers delivered via. Contribute to the development of the country, which in its time focused on a number of areas a scholar who has not only education and upbringing but also scientific and literary ideas Classification of letters in Mahmudkhoja Behbudi's works of art also addressed the issue of Behbudi divides them into two main types.

1. General letters

2. Private letters

classifies as Features of both types of emails explains. Gives examples of types of letters. As you can see Behbudi is not only in the field of school education, but in all spheres of society was careful. Its place in the work of art, from the letter in the speech of the images in the works of art use is very common. Because the speech of the protagonist in the speech of the work through inner experiences, dreams, thoughts, state of mind, reflects his mood. Make it brighter, clearer and more impressive the image of a letter flowing into his heart to express it is artistic enters the work. Today, there are works that are worksIf we take out a letter from the composition, we can see the theme, the idea, it will even have an impact on the course of events. Also, the significance and level of the work is completely lost. Or so there are works that are written in letters from beginning to end. In the play the placement of the letter depends on the skill of the writer. Because, important in revealing the writer's ideological and artistic intentare subject letters. The form, size, method of expression of the letters in the works, manit also depends on the genre in which the image of the psyche is created. Because it's a little epic in terms of the volume of letters found in 
stories with genre patterns shorter, and the content is expressed in a lighter way. But of the letter in the play has a special place. In the short stories that are examples of the middle epic genre the letters encountered and their contents are a wider, larger epic of subject matter the weight of the letter level found in novels with genre patterns is much broader in terms of its impact and significance on the events of the work. In the novels in the letters he encounters, the human psyche, his inner world, his ideas, and their its significance is not only in the reality of the work, but also in its impact on humanity will not remain. The time and in the introduction of the letter to the works as a special object the place has a special place. Take, for example, the history of ancient and medieval times historical letters found in evocative works (various conflicts Andrich in deadly battles) on most political subjects, I - IIand in works depicting World War II, the letter is both positive and negative can be divided into character. Letters of works from the post-war period and the themes of friendship and love are predominant. Along with the subject and time for the letter, space is also a key function does Because if the place is not far (or even if the place is close, if there is no distance between the hearts) in the emotions, in the emotions there will be no revolt, no letter. Letter Works and Their Literary Criticism has a special place in the development of it. As for the stories with small epic genres, the compositional structure of the letters in them, or the letters in the work that the work has an impact on the course of events, the stories have a short plot. The size of the letters in it is also short occurs. However, the letter finds its place in the story. OdilYakubov's "Goodness", Pirimkul Kadyrov's "Ilinj" Shukur Show letters from a series of stories, such as "Spring has passed" by Kholmirzaev possible. For example, in Odil Yakubov's story "Goodness" from Mansurjon there is a letter from. According to the story, Mansurjon he marries a girl named Munnavvarkhanand goes to war three days before their wedding an invitation is coming. You will have to go to the front line.He cracked in his work, he often receives messages from his nephew, whose name is not mentioned in the play goes to the front to help. Lovers love each other miss and write often. One day in a letter from Mansurjon. There was a saying, "Sooner or later we will go to war". For several months after that, no letter came from Mansurjon. Always as the postman crossed the river near their house, a letter from him sometimes Munavvarkhan, who asks if there is one, misses him Duckie hears it from the postman, too, and still waits for the letter. He even sometimes sent his nephew to find out the letter tree and said, "Onedo good and say that I have received a letter from my uncle". Nephew daysIn one, he saw a postman following a large path, and the dough in the housejoy to his aging grandmother and his bride washing her hair in the shade tells the message - the letter tree. Her grandmother's hand is the dough and the bride's mother. The postman rejoiced at the news, his hair half-cut and half-wet run towards. At her grandmother's request, the postman called her neighborhood submitted to the board. They also set the time of the ceremony and take the letter themselves he says they will come. He has been waiting for so long, longing for it, longing for love The heartbreaking news is that the black letter makes you feel bad experience. Even when his nephew returns home in return for this kindness Munavvarkhan did not say goodbye to him and turned his face away in the horse-drawn carriage.

The story does not include the exact text of the letters, but there are ten of them the student consciously understands the excess. Still in it the letters also have an impact on the course of events. Even in the play culminating in the theme of the black letter work, which also served as a knot, the letters found in works of art are of two types in terms of composition. We need to sort it out: 

is given);

1) Messages that appear in the form of text (in this form the exact text of the letter

2) Letters that occur in the form of content. (Letterthe text is not quoted but the content of the letter influences the course of events in the workshows). This means that the letters that appear in the works are in the form of text which are formally expressed, although the text is not quoted in the play we can analyze the content of the letters.

\section{REFERENCES:}

1. Sh. Ahmedova. Letters and Literary Criticism. Tashkent. 2005.

2. Library of Xurshid Davron, L.A. Seneka. Ethical letters for Lutsiy.

3. O'rinboyev A. Jomiy's letters. Toshkent, 1984.

4. H. Homidiy, Sh. Abdullayeva, S. Ibrohimova. "Teacher" Tashkent, 1967.

5. Ibrohim Gofurov. "MUNSHAOT" - It means letters.

6. Marhabo Qo'chqorova, Letters - the mirror of the soul, magazine "World literature”, 2009, № 11. 